\title{
ANALISIS KONSEP DINAMIS PADA ELEMEN ARSITEKTUR BANGUNAN FUNGSI CAMPURAN
}

\author{
Priambudi Dwi Prasetyo ${ }^{1}$, Lutfi Prayogi ${ }^{2}$ \\ ${ }^{1}$ Mahasiswa Jurusan Arsitektur, Fakultas Teknik, Universitas Muhammadiyah Jakarta, Jakarta, \\ Indonesia \\ ${ }^{2}$ Dosen Jurusan Arsitektur, Fakultas Teknik, Universitas Muhammdiyah Jakarta, Jakarta, Indonesia \\ Priamdp08@gmail.com ${ }^{1}$
}

\section{Informasi Naskah}

Diterima: 12/03/2020; Disetujui terbit: 20/05/2020; Diterbitkan: 30/06/2020;

http://journal.uib.ac.id/index.php/jad

\begin{abstract}
Abstrak
Bangunan fungsi campuran adalah sebuah bangunan yang mampu mengakomodasi beragam kegiatan secara kolaboratif. Kini bangunan fungsi campuran sudah menjadi sebuah alternatif disain yang menjadi pilihan guna kegiatan masyarakat kota. Unsur kolaboratif dari bangunan fungsi campuran dirasakan dapat berfungsi secara efisien. Konsep dinamis menjadi salah satu gagasan ideal yang mampu menggambarkan masyarakat kota yang terus berusaha berkembang mengikuti zaman. Konsep dinamis mulai dirasakan berkembangan sejak populernya art deco dimana penggunaan bentuk-bentuk geometris sebagai sebuah gambaran pergerakan menjadi sebuah keharusan. Konsep dinamis seperti gagasan lainnya pasti memiliki keunikannya tersendiri, namun perlu kita cermati bahwa elemen apa saja yang mampu dimanfaatkan sebagai wadah dalam menerapkan konsep dinamis tersebut. Serta dengan cara seperti apa kita dapat menerapkannya secara baik. Dalam penelitian kali ini objek yang dipilih adalah Central Park di Jakarta Barat, South Quarter di Jakarta Selatan dan The Hive di Singapura. Penelitian ini menggunakan metode kualitatif dengan berangkat dari studi literatur, kemudian dilakukan observasi, serta memadukan dokumentasi-dokumentasi yang telah ada sebelumnya dan berkaitan dengan peneltian. Pada penelitian ini ditemukan bahwa terdapat beberapa elemen arsitektur yang umum digunakan seperti fasad, dinding dan langit interior. Selain itu juga didapatkan beberapa manipulasi yang mampu dimanfaatkan dalam penerapan konsep dinamis. Manipulasi tersebut seperti penggunaan bentuk lengkung, kombinasi geometris dan juga pemilihan warna yang cerah dan terkesan aktif.
\end{abstract}

Kata Kunci: Dinamis, Fungsi Campuran, Kolaboratif

\section{Abstract}

The building of the mixed function is an abnate capable of accommodating a variety of activities collaboratively. Now, the mixed function building has become an alternative design that is an option for City community activities. The collaborative element of the building's perceived mixed function can function efficiently. The dynamic concept is one of 
the ideal ideas that describe the city society that keeps trying to thrive in the ages. The dynamic concept began to be experienced in the development since the popularity of Art Deco where the use of Bentul-geometric shapes as a picture of movement becomes a necessity. Dynamic concepts like other ideas must have their own uniqueness, but we need to look at that any element that can be used as a container in implementing the dynamic concept. And in what way we can apply them properly. In this study, the selected object is Central Park in West Jakarta, the South Quarter in South Jakarta and The Hive in Singapore. This research uses qualitative methods by departing from literary studies, then observation, and combining pre-existing documentation and related to the reviewers. In this study it was discovered that there are some commonly used architectural elements such as facades, wall and interior ceilings. There are also several manipulations that can be utilized in the implementation of dynamic concepts. The manipulation is like the use of curved shapes, geometric combinations and also bright color selection and impressed active.

Keywords: Dynamic, Mixed Use Building, Collaborative

\section{Pendahuluan}

Istilah dinamis dengan arsitektur memiliki hubungan yang amat erat. Dinamis dalam KBBI memiliki arti penuh semangat dan bertenaga sehingga mampu bergerak, memiliki keterkaitan sebagaimana ilmu arsitektur itu sendiri yang terus mengikuti perkembangan zaman dalam penerapannya, serta terus memiliki ambisi untuk membuat ruang hidup menjadi lebih baik dan menarik dari zaman ke zaman. Dinamis sebagai unsur pada arsitektur, dinilai memiliki peran yang cukup signifikan, hal tersebut dapat kita lihat dari sifatnya yang fleksibel atau mampu dikolaborasikan dengan berbagai elemen pada arsitektur. Unsur dinamis pada arsitektur telah lama menjadi sebuah simbol dari sesuatu yang dinilai progresif atau memiliki kemampuan untuk terus bergerak/berubah, menjadikannya sempurna sebagai simbol kehidupan masyarakat modern saat ini.

Konsep dinamis sebagai salah satu gagasan arsitektural yang memiliki potensi dalam keterkaitannya dengan disain kota, tentunya perlu memiliki dasar-dasar dalam penerapannya. Konsep dinamis sebagai sebuah simbol pergerakan yang sejalan dengan pola masyarakat kota yang ingin terus berkembang dalam kehidupannya, sekiranya mampu menjadi unsur penting yang dapat diterapkan dalam sebuah gagasan disain arsitektural. Namun dalam menerapkan konsep dinamis ini tentunya tidak dapat sembarangan, karena akan menjadi sia-sia apabila upaya yang dilakukan tidak cukup mampu dalam menyampaikan kesan dinamis.

Lokasi objek penelitian ini, berada di Kawasan Jakarta dan juga di Kawasan Nanyang Technological University, Singapura. Untuk objek yang berada di Kawasan Jakarta adalah 
Central Park yang memiliki fungsi sebagai mall dan apartemen. Kemudian South Quarter yang memiliki fungsi Mall dan Kantor sewa. Sedangkan untuk yang berada di NTU Singapura, adalah The Hive yang memiliki fungsi Education Space dan Commercial Space.

Dalam melakukan penelitian ini, terdapat tujuan yang ingin dicapai oleh peneliti. Tujuan tersebut adalah peneliti mampu memahami secara baik mengenai penerapan konsep dinamis pada bangunan yang memiliki fungsi campuran. Selain itu peneliti juga berharap untuk dapat mengetahui manipulasi-manipulasi yang dapat digunakan dalam penerapan konsep dinamis secara efektif pada elemen-elemen arsitektural yang juga potensial.

\section{Kajian Pustaka}

\subsection{Definisi Dinamis}

Merujuk pada Kamus Besar Bahasa Indonesia (KBBI) dinamis memiliki arti keadaan penuh tenaga sehingga mampu cepat bergerak. Secara etimologi, istilah dinamis berasal dari kata bahasa Perancis yakni "dynamique" yang diambil dari bahasa Yunani yang berarti "kekuatan". Selanjutnya, Meriam - Webster juga mendefinisikan dinamis sebagai sesuatu yang terus aktif dan berubah. Selain itu dinamis juga diartikan sebagai kondisi seseorang yang memiliki banyak energi. Jolan Srisusana A. Dan Meydian Sartika D. (1999) menjabarkan kriteria dinamis yaitu terbentuk dengan keseimbangan asimetri atau dapat juga dengan simetri yang imajinatif, memiliki irama serta memiliki pusat perhatian.

Dinamis juga dapat dipahami sebagai sebuah istilah dalam beradaptasi dengan perkembangan zaman, dimana dalam dunia Arsitektur sebuah perancangan harus mampu secara dinamis mengikuti perkembangan baik dalam segi estetika maupun segi teknologi. Dalam praktiknya istilah dinamis seringkali digambarkan lewat kombinasi bentuk geometri yang menggambarkan pergerakan.

\subsection{Definisi Elemen}

Menurut KBBI arti elemen secara umum adalah bagian yang penting, yang dibutuhkan dari keseluruhan yang lebih besar. Dalam buku Ching (2007) dijelaskan bahwa bentuk berawal dari sebuah titik yang kemudian bergerak berwujud sebuah garis menjadi elemen dimensi pertama. Apabila garis tersebut berpindah maka kita mendapati elemen kedua yakni bidang. Yang selanjutnya bidang tersebut dapat berbenturan membentuk badan elemen tiga dimensi yang disebut ruang. Elemen-elemen tersebut nantinya mampu mengarahkan persepsi pengguna bergantung dari bagaimana kita mencoba mendesainnya.

Elemen vertikal yang terbentuk dari pergerakan sebuah titik, biasanya diaplikasikan seperti pillar, kolom atau tugu menghasilkan titik-titik tertentu dalam ruang, Ching (2007). Elemen dua dimensi yang terbentuk dari pergerakan garis menjadi sebuah bidang memiliki tiga jenis manipulasi yaitu bidang dinding, bidang atas, dan bidang dasar, Ching, (2007).

\subsubsection{Bidang dinding}

Bidang dinding merupakan bidang yang berorientasi vertikal yang menyebabkannya bersifat aktif dalam sudut pandang pengguna yang normal. Bidang dinding juga memiliki 
peran aktif dalam faktor pembentukan dan penutupan dari sebuah bidang arsitektural. Bidang dinding eksterior mengisolasikan sebagian ruang untuk menciptakan suatu lingkungan interior yang terkendali.

Bidang-bidang dinding interior mengatur ukuran dan bentuk ruang di dalam sebuah bangunan. Sifat-sifat visualnya, hubungannya satu sama lain dan ukuran serta distribusi bukaan-bukaan di dalam batas-batasnya akan membentuk baik kualitas ruang yang tercipta maupun tingkat keberdekatan ruang yang terkait.

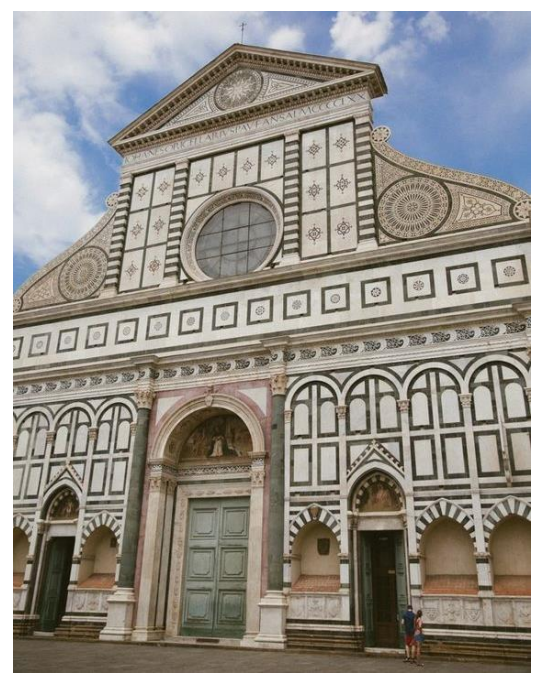

Gambar 2.1 Bidang dinding eksterior, S. Maria Novella, Florence

Sumber: https://www.pinterest.ru/pin/328199891598814858/ (diakses April 2020)

\subsubsection{Bidang atas}

Sebuah bidang yang membentuk pelindung bagi ruang-ruang dalam dari sebuah bangunan. Selain itu bidang atas juga termasuk langit-langit yang menutup ruang dibawahnya. Bidang langit-langit biasanya tidak terjangkau langsung oleh kontak fisik sang pengguna, hanya terbatas melalui kontak visual dalam sebuah ruang. Keberadaannya dapat bertempat di sisi bawah sebuah lantai atas atau bidang atap.

Bidang atas ini seringkali mengekspresikan bentuk struktur bangunanya yang membentang dalam ruang. Selain itu bidang atas ini juga dapat menggantung dan memiliki fungsi sebagai lapisan penutup bagian atas sebuah ruang. Sebagai sebuah lapisan yang terlepas, bidang atas dapat menjadi elemen penaung utama yang menyatukan ruang-ruang berbeda dalam sebuah bangunan. Bidang atas ini dapat diperlakukan secara aktif menjadi bidang artistik, ataupun secara pasif sebagai sebuah bagian pelengkap bangunan. Maka dari itu bentuknya sangat mungkin dimanipulasi untuk mendapat kualitas visual ataupun lainnya. 


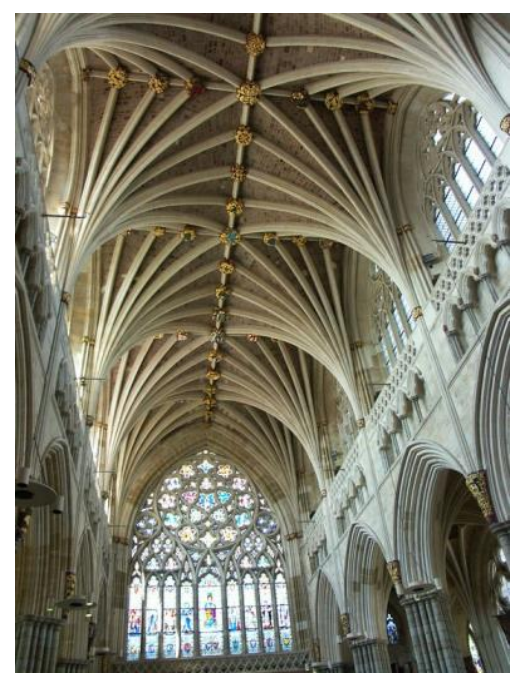

Gambar 2.2 Langit-langit Gereja Cathedral, Roma, Italia

Sumber: https://www.pinterest.ru/pin/432978951649204984/ (diakses April 2020)

\subsubsection{Bidang Bawah}

Seringkali dicontohkan sebagai bidang lantai tempat pondasi fisik kita berada dalam sebuah bangunan. Lebih dari itu bidang atap juga dapat disebut bidang dasar, karena bidang atap berupaya menjadi permukaan penutup ruang yang berada dibawah tempat kita berjalan ataupun beraktifitas. Bangunan dapat menyatu dengan bidang dasarnya, duduk diatasnya, atau terangkat (Ching, 2007).

Dalam manipulasinya, sebuah bidang dasar dapat dijadikan podium bagi sebuah bentuk bangunan, keberadaannya dapat ditinggikan untuk memberi kesan penghormatan atau suci, diberikan kanstin, hingga tak jarang diberi sentuhan pahat atau seni ukir. Bidang dasar sebagai elemen horisontal dapat berupa sebuah penutup didasar sebuah ruang, ataupun sebuah bidang yang lebih artifisial, ditinggikan membentangi sebuah ruang dengan penopang-penopangnya. Bentuk, warna, serta polanya tetap berpengaruh dalam menentukan sejauh mana batas-batas spasialnya sebagai sebuah elemen arsitektural.

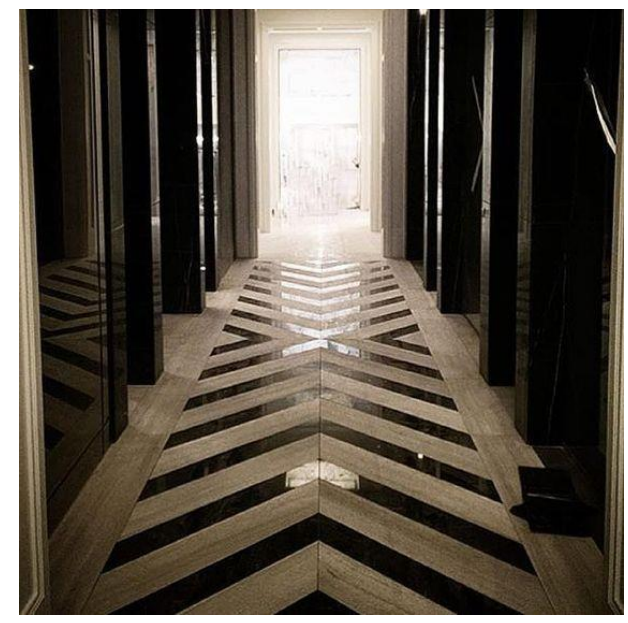

Gambar 2.3 Bidang dasar berupa lantai

Sumber: https://www.pinterest.ru/pin/334251603595920988/ (diakses April 2020)

JAD - Vol.01 / No.01, Juni 2020 I 5 


\section{Metode Penelitian}

Dalam pengumpulan data terdapat beberapa tahapan yang perlu dilakukan untuk mendapat data. Tahapan pengumplan data memuat beberapa Teknik dalam cara pengambilannya. Beberapa Teknik pengumpulan data tersebut adalah sebagai berikut:

\subsection{Lokasi Penelitian}

Dalam Penelitian ini peneliti mengambil objek yang bertempat di Kawasan Central Park dengan fungsi Mall dan Apartemen di Jakarta Barat, Kawasan South Quarter dengan fungsi Mall dan Kantor Sewa di Jakarta Selatan dan The Hive di Kawasan NTU, Singapura.

\subsection{Studi Literatur}

Mengumpulkan informasi terkait yang berasal dari literatur didapat dari internet, ataupun buku-buku yang ditulis berdasarkan peneliti sebelumnya. Informasi ini mampu membantu dalam memberikan landasan awal dari penelitian landasan awal dari penelitian yang akan dilakukan. Data yang dapat diperoleh dari Teknik ini berupa prinsip-prinsip dasar dari konsep dinamis, pemahaman elemen-elemen arsitektural, inovasi dan kombinasi dari prinsip dinamis pada elemen arsitektur.

\subsection{Observasi}

Melakukan kunjungan langsung ke tempat lokasi atau objek yang telah ditentukan, bangunan tersebut adalah bangunan yang telah menerapkan konsep dinamis, serta merupakan bangunan yang termasuk kedalam bangunan fungsi campuran (mixed use). Dari teknik pengumpulan data ini didapat dokumentasi aktual tentang elemen-elemen arsitektur pada lokasi studi kasus.

\subsection{Studi Dokumentasi}

Melakukan pencarian dokumentasi sejarah dari objek penelitian yang biasanya memuat setiap poin dari objek penelitian tersebut, serta perkembangan yang telah dilakukan. Teknik pengumpulan data ini membantu peneliti dalam memilih lewat dokumentasi yang telah didapatkan, serta menghubungkannya dengan prinsip-prinsip menurut kajian teori dari studi literatur . 


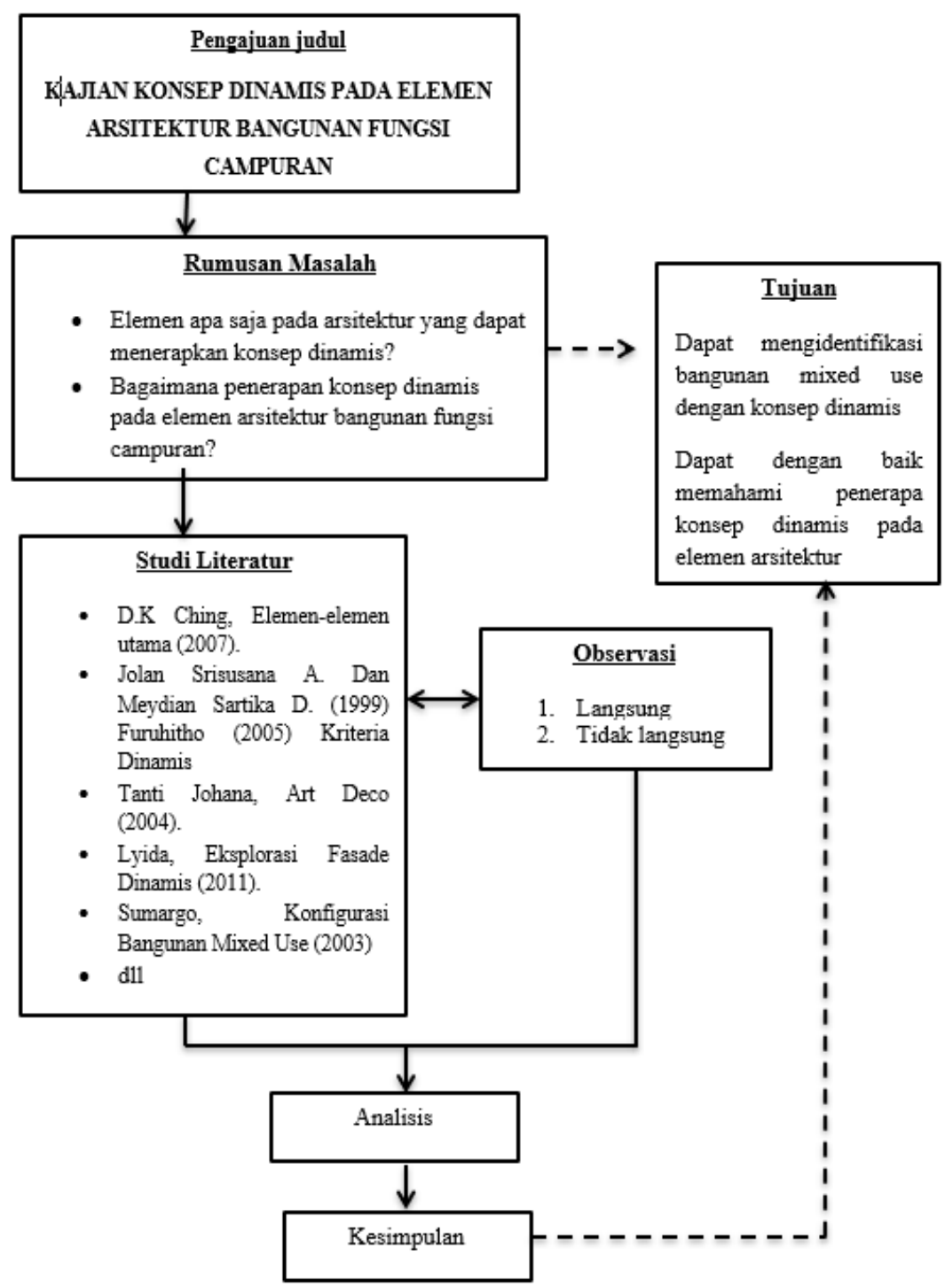

Gambar 3.1 Diagram Alur Berpikir

Sumber: Pribadi, 2019

\section{Hasil dan Pembahasan}

Bab ini akan membahas hasil yang didapatkan dari survey yang dilakukan peneliti pada ketiga lokasi objek penelitian yaitu Central Park, South Quarter dan The Hive. Untuk pembahasannya akan menghubungkan kondisi eksisting objek dengan teori mengenai karakter konsep dinamis dan elemen-elemen arsitektur yang dapat dimanipulasi yakni bidang atas, bidang dinding dan bidang dasar.

\subsection{Bidang Atas}

Pada gambar 4.1 dapat dilihat bahwa lower ground memiliki bidang atas atau langit-langit yang berbentuk melengkung oval yang dikombinasikan dengan bentuk linier horisontal yang berirama pada permukaannya. 


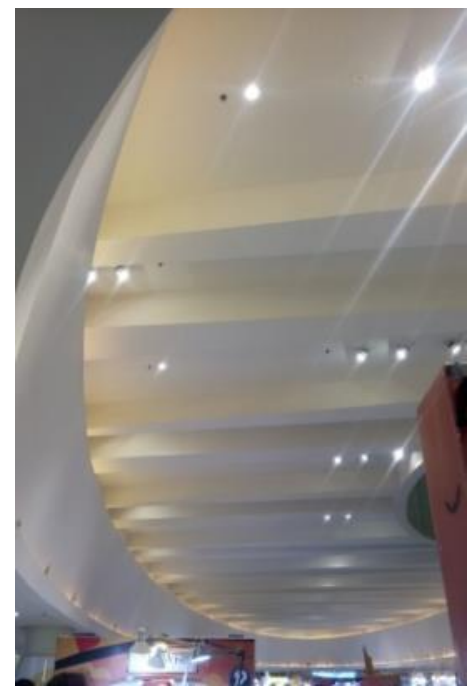

Gambar 4.1 Bidang atas Lower Ground, Central Park Sumber: Dokumentasi Pribadi, 2019

\subsection{Bidang Dinding}

Selanjutnya bidang dinding, yaitu bidang yang biasanya berorientasi vertikal dan tampak nyata(dapat dirasakan secara fisik). Bidang dinding ini terdiri dari dua jenis yaitu dinding luar(eksterior) atau yang sering disebut sebagai fasade dan juga dinding dalam(interior). Bidang dinding ada yang melingkupi sekeliling ruang, ataupun hanya menghalangi beberapa sisi saja. Pada gambar 4.2 adalah contoh dari bidang dinding eksterior yang mengkombinasikan lengkungan yang mengarah ke dalam ataupun ke luar.

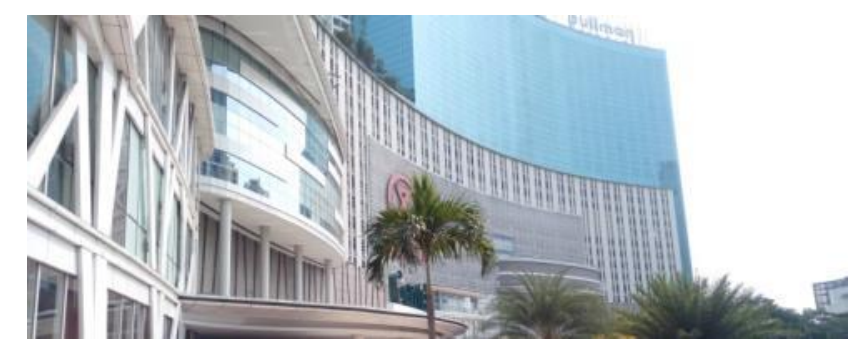

Gambar 4.2 Bidang Dinding Luar

Sumber: Dokumentasi Pribadi, 2019

\subsection{Bidang Dasar}

Gambar 4.3 adalah bidang dasar pada area dalam Central Park dimana bidang dasarnya mengaplikasikan kombinasi bentuk linier dengan membentuk pola melengkung disepanjang area pengunjung berjalan. 


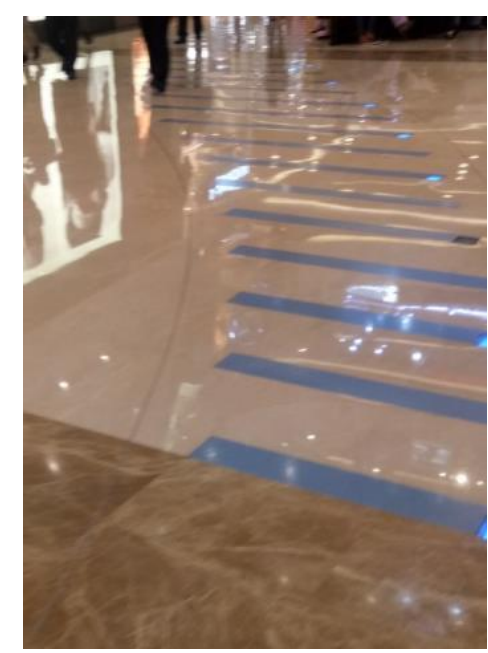

Gambar 4.3 Bidang dasar, Central Park

Sumber: Dokumentasi Pribadi, 2019

\subsection{Kombinasi Bentuk Geometris}

Pertama adalah manipulasi lewat bentuk-bentuk geometris, dimana bentuk-bentuk dasar geometris dipadukan sehingga menghasilkan bentuk akhir yang memiliki keunikan, serta memiliki dinamika. Untuk manipulasi, dapat diterapkan terhadap hampir setiap elemen fisik arsitektur, seperti pada contoh gambar 4.4 Manipulasi bentuk geometris diterapkan pada bidang atas atau permukaan langit-langit Central Park, dengan menghadirkan bentuk elips dan lingkaran, serta bentuk-bentuk linier yang berirama dengan bentuk elips.

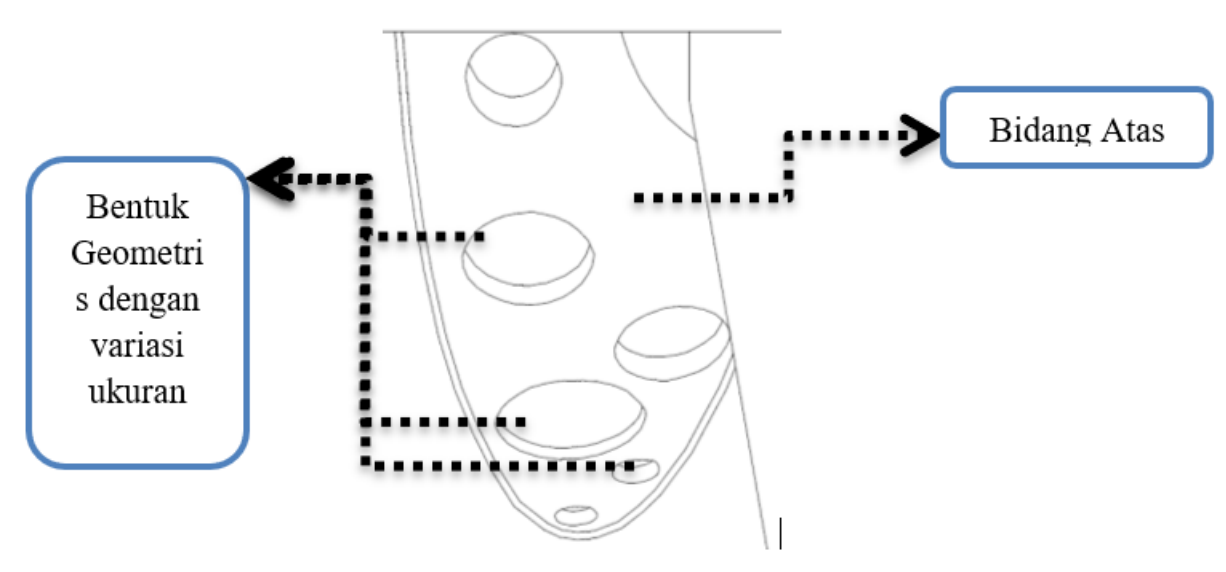

Gambar 4.4 Bidang atas dan bentuk Geometris

Sumber: Dokumen Pribadi, 2019

\subsection{Kombinasi Warna}

Selain dengan memanfaatkan keunikan dari bentuk-bentuk geometris dalam menghadirkan visual yang dinamis juga dapat bermain dengan warna yang dipilih. Hal tersebut seperti yang dapat peneliti identifikasi pada jembatan layang penghubung yang terdapat di Central Park. Pada jembatan ini sang disainer memilih 
untuk memainkan degradasi warna yang cukup cerah pada sisi jembatan, kesan tersebut dirasa mampu memberikan kesan dinamis yang lebih kuat, selayaknya jalur penghubung tersebut yang aktif digunakan pengunjung.

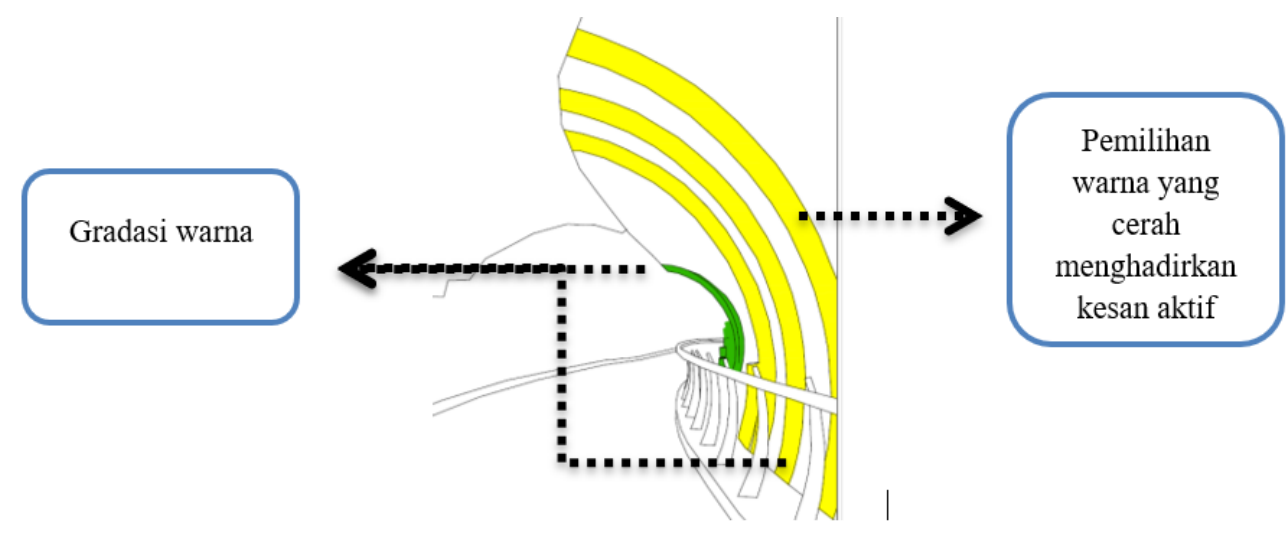

Gambar 4.5 Kombinasi warna

Sumber: Dokumen Pribadi, 2019

\subsection{Tekstur Visual}

Selain pada bidang lantai yang dapat diidentifikasikan sebagai elemen yang dinamis, kolom-kolom yang terdapat pada hive juga memiliki tekstur yang tidak lazim seperti kebanyakan kolom yang memiliki tekstur halus. Pada bangunan Hive kolom-kolomnya memiliki tekstur seperti bergelombang, tekstur tersebut dapat dilihat seperti sebuah aliran yang bergerak dari atas kebawah apabila kita padukan tiap lantainya.

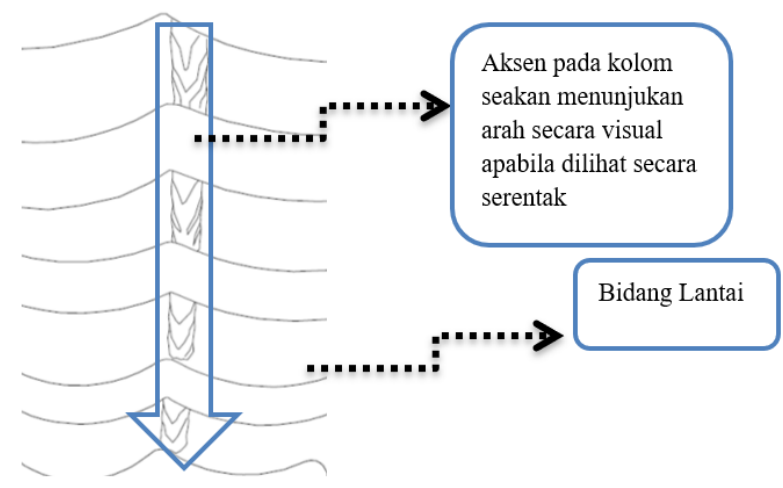

Gambar 4.6 Aksen Visual pada kolom

Sumber: Dokumen Pribadi, 2019

\subsection{Tata Cahaya}

Prinsip dinamis dalam penerapannya juga dapat kita temukan pada pencahayaan yang hadir dalam sebuah ruang, baik itu pencahayaan yang bersumber alami ataupun tidak. Dari data yang telah didapat, sehingga dapat mengidentifikasi beberapa sumber cahaya yang mampu membantu dalam mempertegas prinsip 
dinamis dalam sebuah bangunan. Salah satu contoh sumber cahaya yang mampu optimal dalam memberikan dinamika dalam ruang adalah pada bangunan Hive, yang dimana pada bagian tengah masa bangunan tersebut terdapat bukaan di permukaan atapnya. Sehingga mampu menghadirkan cahaya yang optimal pada siang hari dan juga sekaligus memberikan kesan dinamis seiring perubahaan cahaya matahari yang didapat setiap waktunya.

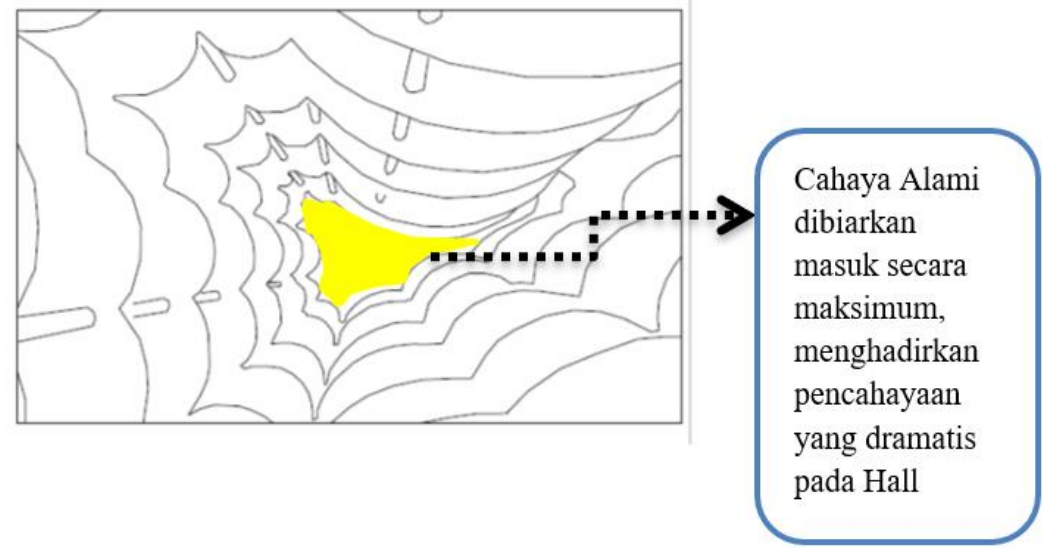

Gambar 4.7 Sumber cahaya alami

Sumber: Dokumen Pribadi, 2019

\section{Kesimpulan}

Dalam menerapkan konsep dinamis terdapat beberapa manipulasi atau cara-cara yang dapat digunakan untuk menerapkan konsep dinamis pada elemen bangunan. Bersumber dari identifikasi pada ketiga, studi kasus bangunan fungsi campuran yang telah diteliti didapat beberapa manipulasi yang kerap digunakan, seperti kombinasi bentuk-bentuk geometri, pemilihan warna, tekstur visual, pemilihan bentuk sirkulasi, serta tata cahaya. Selanjutnya, pada penelitian kali ini elemen-elemen yang dapat menerapkan konsep dinamis tersebut dikelompokan menjadi bidang pembentuk ruang yang terdiri dari bidang atas, bidang dinding, dan bidang dasar.

1. Bidang atas

Bidang datar yang biasanya terletak diatas dari sebuah ruang serta memiliki orientasi horisontal. Bidang atas dapat berupa selubung pekat dan solid yang membentuk plafon, hingga atap, atau dapat berupa selubung transparan berupa visual yang mengekspos struktur atap.

\section{Bidang dinding}

Bidang dinding biasanya berposisi sejajar dengan ruang, serta memiliki orientasi vertikal. Sifat visualnya cenderung kuat, serta seringkali menjadi sebuah batasan antara atau dalam ruang. Manipulasi pada sebuah bidang dinding seringkali ditemukan sebagai dinding pemisah antar ruang, namun juga dapat berupa partisi-partisi atau sekat yang memisahkan area dalam satu ruang yang sama. 


\section{Bidang dasar}

Bidang dasar merupakan bidang datar yang memiliki sifat yang sama dengan bidang atas namun letaknya berada dibawah sebuah ruang. Bidang dasar biasanya berupa alas atau lantai sebuah ruang, sedangkan pada sebuah massa bertingkat bidang dasarnya dapat berupa bidang atas dari lantai dibawahnya.

Pada penelitian ini sesungguhnya belum dapat menentukan apakah konsep dinamis yang diterapkan pada elemen-elemen arsitektur tersebut dapat sampai dirasakan oleh setiap lapisan pengunjung. Maka dari itu, diharapkan kedepannya akan ada penelitian yang mampu memperhitungkan hal tersebut, dimana konsep dinamis yang pengunjung rasakan mampu diteliti secara konkret.

\section{Ucapan Terimakasih}

Terimakasih kepada seluruh pihak yang telah membantu dalam penyelesaian laporan penelitian ini. Terutama untuk Bapak Lutfi Prayogi selaku dosen pembimbing yang telah memberikan banyak masukan serta koreksinya. Serta pihak-pihak lain yang tidak dapat saya sebutkan satu persatu. Dibalik segala kekurangan yang masih terdapat dalam penelitian ini peneliti harap laporan penelitian ini mampu memberikan hal yang positif bagi pembaca dan khususnya bagi peneliti sendiri. Atas perhatian pembaca saya ucapkan terimakasih.

\section{Daftar Pustaka}

Adi Susilo, Gatot. 2009. Arsitektur Jengki: Bergeometri Yang Kreatif. Spectra, Nomor 13 Volume VII. Bandung.

Allen, P.S. \& Stimpson, M.E. (1994). Beginnings of Interior Environment. New Jersyey: Macmillan College Publishing Company, Inc.

Darmaprawira, 2002, Sulasmi, Warna: Teori dan Kreativitas Penggunaannya, Bandung, ITB.

Dinapradipta, Asri. Az-Zahro, Fatimah. 2018. Coworking space dengan konsep pencahayaan yang dinamis. Jurnal sains dan seni ITS vol. 7 No. 2. Institut Teknologi Sepuluh Nopember (ITS).

DK. Ching. 2007. Bentuk Ruang dan Tatanan. Edisi ketiga. Jakarta : Erlangga.

Furuhitho, X. 2005, Teori Arsitektur 1, http://furuhitho.staff.gunadarma.ac.id/

Honggowidjaja. 2003. Pengaruh signifikan tata cahaya pada desain interior. Dimensi interior, vol. 1, no. 1 Universitas Kristen Petra.

lyati, Wasiska. Vioveta, Lavica. Santosa, Herry. Eksplorasi Fasade yang Dinamis dengan Materal Alumunium Composite Panel pada bangunan MOG di Malang. Universitas Brawijaya. Malang.

Lydia, 2011. Pemanfaatan Warna Untuk Fasade Dinamis. Prosiding Seminar Nasional AVoER. Universitas Sriwijaya. Palembang.

Martokusumo, Widjaja. 2017. Pemaknaan Tempat dalam Pelestarian Arsitektur. Prosiding Seminar Heritage IPLBI.

Pawitro, Udjianto. 2010. Fenomenan Post-Modernisme dalam Arsitektur Abad ke -21. Jurnal Itenas Rekayasa No.1 Vol 14. Bandung.

Priatman, Jimmy. 2005. Bangunan Tinggi Multi Fungsi Sebagai Sintesis Arsitektur dan

12 I JAD - vol.01/ No.01, Juni 2020 
Struktur. Dimensi Teknik Arsitektur Vol. 33 No. 1, Universitas Kristen Petra.

Sumargo, P. S. (2003). Penerapan Konsep Mixed Use dalam Pengembangan Kawasan Kota. KILAS Jurnal Arsitektur FTUI, 58.

Widati Titiani. 2015. Pendekatan Kontekstual dalam Arsitektur Frank Lloyd Wright. Jurnal Perspektif Arsitektur. Vol. 10/No.1. Palangka Raya.

Zubaidi, Fuad. 2010. Telaah Konsep Frank O Gehry dalam Rancangan Arsitektur. Jurnal "ruang" Volume 2 No. 2. Universitas Tadulako. Palu. 